\title{
Mobile Educational Games For Learning Sirah Nabi: Development And Usability Evaluation
}

Nadzirah Kamarazaman, Roslina Ibrahim*, Rasimah C.M.Yusoff, Norziha M. M Zainudin, Suraya Yaacob, Yazriwati

Yahya, Husna Hafiza R. Azami

Faculty Technology and Informatics Razak, Universiti Teknologi Malaysia, 54100 Kuala Lumpur, Malaysia.

*Corresponding author: iroslina.kl@utm.my

\section{Article history}

Received: 2021-03-10 Received in revised form: 2021-05-19 Accepted: 2021-05-20 Published online: 2021-10-30

\begin{abstract}
The pervasive use of the internet and mobile phone among the age group $5-17$ years old makes learning through these media an attractive proposition. Mobile learning presents a flexible and inventive way of learning as well as the new normal. On the other hand, learning Sirah is an essential part of every Muslim in the world in order to understand what has happened in the past regarding our beloved prophet and to learn from his behaviour and follow his sunnah. However, past studies shown that the traditional learning approach seems dull and not interesting enough. Mobile learning thus offers a new solution in learning the Sirah and similar subjects most students find of low interest and dull. The study used a quantitative approach using survey for data collection; and was divided into two phases: Sirah Game Prototype Design and Usability Evaluation phase. The ADDIE model was adapted as a model to guide instructional design process and development of the Sirah mobile applications with five phases throughout the process. An evaluation model consisted of seven components namely Game Usability, Mobility, Learning Content and Playability, Satisfaction, Efficiency was implemented. The findings suggested that students are highly interested in the use of the games for learning, able to learn Sirah subject in better ways by using the games and learning with games was found as enjoyable way to learn. This study adds more to Islamic digital content and enhances the learning approach for Sirah subject. We hope to contribute more towards Islamic digital content in the future for the benefit of our ummah and community.
\end{abstract}

Keywords: Mobile learning, Educational games, Usability Evaluation, Sirah Nabi 


\subsection{INTRODUCTION}

Nowadays, children are exposed to mobile technology like never before, they use mobile phones and tablets in their daily activities for both leisure and as a learning medium (Duh, Koceska \& Koceski, 2017, Castillo, R. E. et al. (2019)). Children today are also known as the digital native generation because they live in a modern world where all kinds of technologies revolve around them (Ibharim \& Yatim, 2014). They are getting more exposure to use the smartphone because they are using it from the early stage of their lives. A Survey from the Malaysian Communications and Multimedia Commission (MCMC) has found that $83.2 \%$ of children from ages of five to seventeen were internet users and $93 \%$ of them surf the internet using smartphones (The Star Online, 2018).

The recent Covid-19 pandemic has made mobile learning a compulsory medium for both school and higher education students. Schools and learning institutions all over the world have shifted from physical to online mediums due to movement restrictions. Mobile learning offers various advantages due to its flexibility and innovative features. Mobile learning allows educators to generate online learning solutions for students, which can be, used anywhere and anytime which is impossible to do using a traditional educational approach (Jou, Tennyson, Wang, \& Huang 2016, Jaafar et al, 2020, Roslina et al 2017). However, there are some limitations in mobile devices employed in mobile learning including limited processing power, small screen size, connectivity, and data entry methods (Nielsen \& Budiu, 2013). In this case, usability plays an important role in the success of a mobile application. Usability makes the system easier to use and makes sure that it fits the learner's requirement (Parsazadeh et al 2018). Mobile learning helps to promote active learning and inspire shy students to interact. Poor usability will decrease students engagement and consequently cause dropouts among them.

One of the challenging subjects to score is Sirah because it is similar to history whereby it requires students to remember the important dates, names and events that occur in the past. This is challenging for the student to remember due to lack of context within the subject itself. Similarly, most students found History as boring and they have low interest on the subject (Chee-Huay \& Kee-Jiar, Y. 2015). Based on the result of Ujian Penilaian Kelas KAFA (UPKK) examination by Jabatan Kemajuan Islam Malaysia (JAKIM) from 2015 until 2018, it is shown that Sirah subject has the lowest scores in 2015, 2016, and 2018 (Suhaila, 2018; Zanariah, 2017; Statistik Keputusan UPKK 2015 Peringkat Kebangsaan, 2015). Thus, a more innovative learning approach to overcome these problems is proposed such that students can learn Sirah in a more fun way using more interactive approach.

\subsection{LITERATURE REVIEW}

Educational game is regarded as a recent technology with full potential to be adapted as teaching and learning approach as stated in various literatures. Educational games were said to be able to increase student motivation to learn (Ibrahim et al 2011, Barnes et al, 2007). Additionally, educational games are also regarded as a highly interactive tehcnology that able to offer immediate feedback to the student, support skills and influence behaviour changes (Jaspaljeet et al, 2008). Despite that, many issues are still lack of exploration includings user assesment and perceptions as well as games design characteristics (Nagalingam \& Ibrahim, 2020, Marissa \& Ibrahim 2019).

The following section discusses past studies related to educational games design process and evaluation.

a) Mobile Educational Game Design Process

Page | 108 
Games are effective educational tools because they are fun, facilitate learning and motivate user (Paiva et al, 2016). There are many good solutions provided for game development, but there are quite generic when it comes to developing educational games (Paiva et al., 2016). ADDIE model is a design model that involves basic stages that are not complicated and easy to learn. ADDIE may be applied in an educational setting for teachers and educators (Hidayanto et al., 2017). It has clear instructions; and various learning strategies with a series of design, development and evaluation can be integrated (Sasaki et al, 2017).

b) Usability and Evaluation

Many studies have identified the benefits of usability evaluation in the application development life cycle (Harrison et. al, 2013; Shitkova et. al, 2015). Nielsen stated that "usability is a necessary condition for survival of the web applications" (Nielsen, 1994). Usability is also crucial for the success of a mobile application.

Usability or "ease of use" can mean to make products and systems easier to use, and to adapt them more closely to users' requirements. Poor usability reduces user productivity and accordingly causes a dropped out among users (Shitkova et al., 2015). Usability also has advantages in reducing training costs, enhanced quality of work, increased productivity, and improved user satisfaction.

ISO 9241-11 (1998) define usability as "the extent to which a product can be used by specified users to achieve specified goals with effectiveness, efficiency and satisfaction in a specified context of use" (Bevan, 1998). Furthermore, ISO/IEC 9126-1, defines usability as "the capability of the software product to be understood, learned, used and attractive to the user, when used under specified conditions". There are many usability evaluation methods as discussed in Zaibon (2015). There are five usability components suggested by Nielsen (2013) which consist of learnability, efficiency, memorability, errors and satisfaction.

c) Usability Evaluation and Component

Usability evaluation is done for users to find out how they can easily reach the application goals. Mobile devices usability and applications are different from other software systems because of their features. There are four usability components proposed by Zaibon (2015): game usability $(\mathrm{GU})$, mobility (MO), learning content (LC) and playability (PA). Game Usability (GU) is defined as how the user measures the interface and game controls aspects when they interact with the game (Zaibon, 2015). GU is one of the components use to measure usability evaluation. Korhonen and Koivisto (2007) discovered that GU is related to gameplay and cannot be ignored in a game evaluation. Generally, a player will not lose their interest while playing the game if the game usability is good.

Mobility (MO) can be described as how easy the player to enter the game and can user play the game anywhere and at any time using mobile platform according to the user preference (Zaibon 2015, Scepanovic \& Radunovic 2015). Learning content (LC) components explicitly focused on measuring the learning content. It must include instructive and helpful information so that the user can understand the game applications when there playing it. Playability (PA) is to test how the game is playable and consistent and to test whether the game is meaningful and most importantly not bored the player (Zaibon, 2015). Olsen, Procci \& Bowers (2011) said it is difficult to capture the PA component because PA has been yearned in educational games, but there are not widely used to measure usability. PA components are crucial because it is robust and happen when the user interacts with the gameplay and rules. 


\subsection{RESEARCH METHODOLOGY}

This study was divided into two phases: Sirah Game Prototype Design and Usability Evaluation phase; using ADDIE, an instructional model to guide the design process (as in Figure 1).

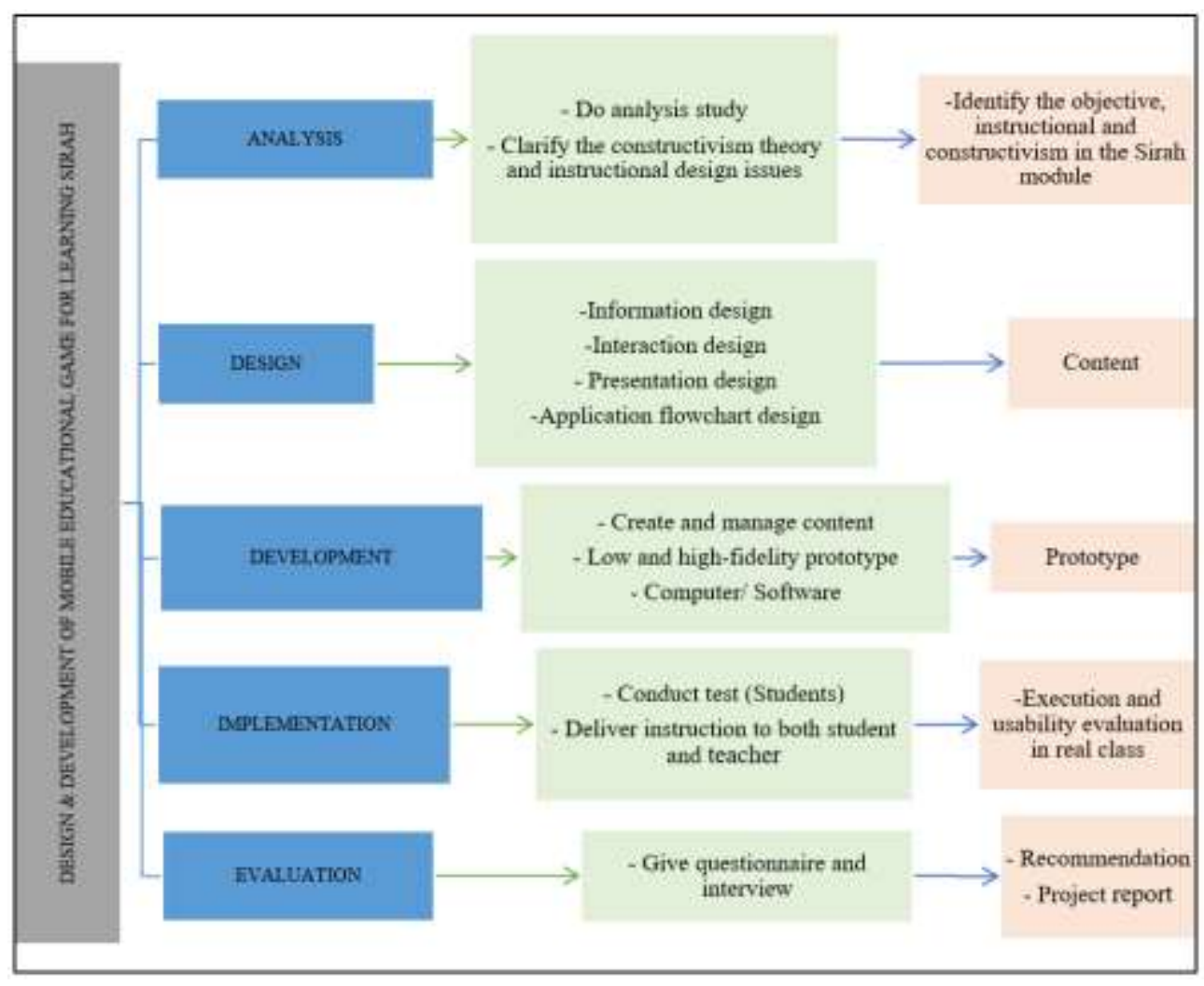

Figure 1 Sirah Game Design Framework

This study adapted an evaluation strategy that consists of four components: Game Usability, Mobility, Learning Content and Playability that can be implemented in MEG (Zaibon, 2015). Another three components were adapted from Nielsen (2013): Satisfaction, Efficiency and Learnability, refer to Figure 2. 


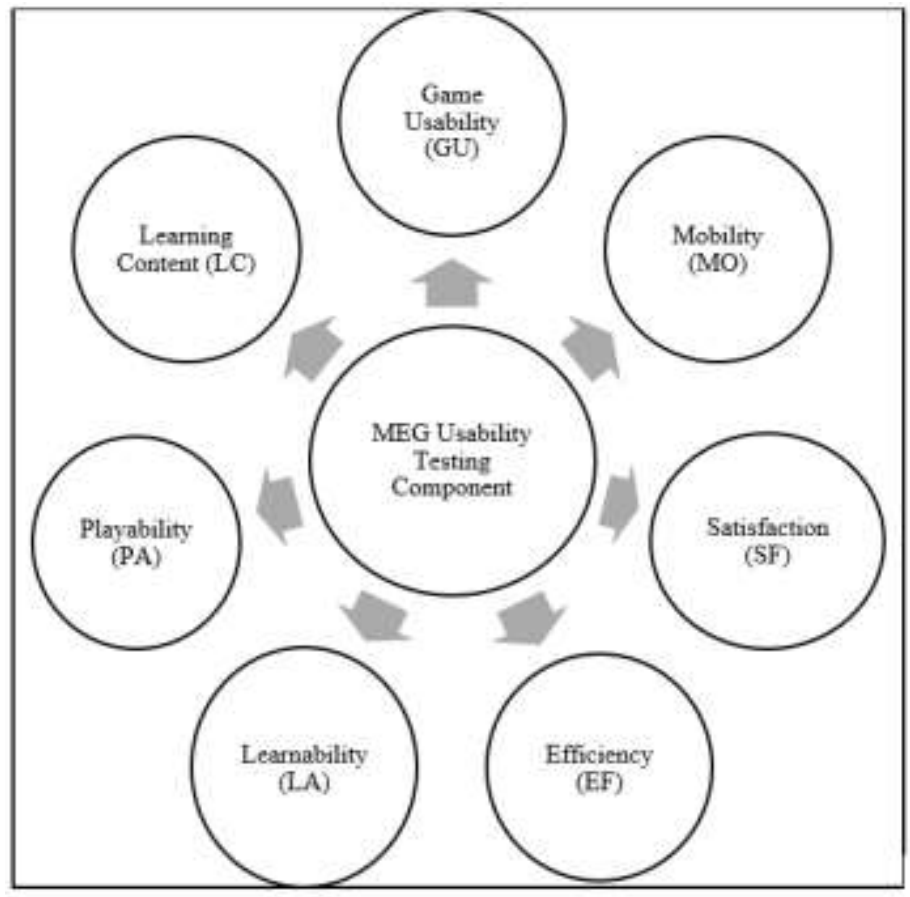

Figure 2: Proposed Mobile Educational Games Usability Evaluation Model

The ADDIE model is used as an instructional design to help in the development process of Sirah mobile applications. The five phases of the development process which is analyzed, design, develop, implement, and usability evaluation. Each phase of the process below conducted based on the respondent criteria that are year three of primary school (Figure 1).

i)

Analysis Phase

In this phase, the target respondents for the study were identified and the subject to be used as educational game content was also determined. The game component and genre were planned to ensure it fits and matches with the content. Textbook for the Sirah content was also analyzed to select suitable content for the games. The initial interface design was done, and game contents were developed for the purposes. The deliverables for this phase are initial games content design and initial games interface/navigation design.

ii) Design Phase

For the design phase, the interface of the game was design using digital medium and game content was adapted into the interface. Since the games have 2 main modules which Teka Silangkata (Cross Word) and Carian Perkataan (Word Search), we designed the first module and several levels followed by the second modules and its level. Regular evalaution also conducted to ensure the design ais good and easily understand by student. For design purposes, Sirah game involves a low-fidelity and high-fidelity prototype. A low-fidelity prototype was used to sketch the flow and interface; while a high-fidelity prototype was built and tested on five children for their initial reactions. The deliverables for this phase are to finalize games content for each modules and levels and finalize games interface and navigation design. Figure 3 shows the modules of the Sirah game. This application consists of several pages with clear visual content so that students can easily browse and use this app without any help. There are four levels of the game in the 'Carian Perkataan' and 'Teka Silang Kata' section designed according to the syllabus of 'Sirah' year three primary schools. 


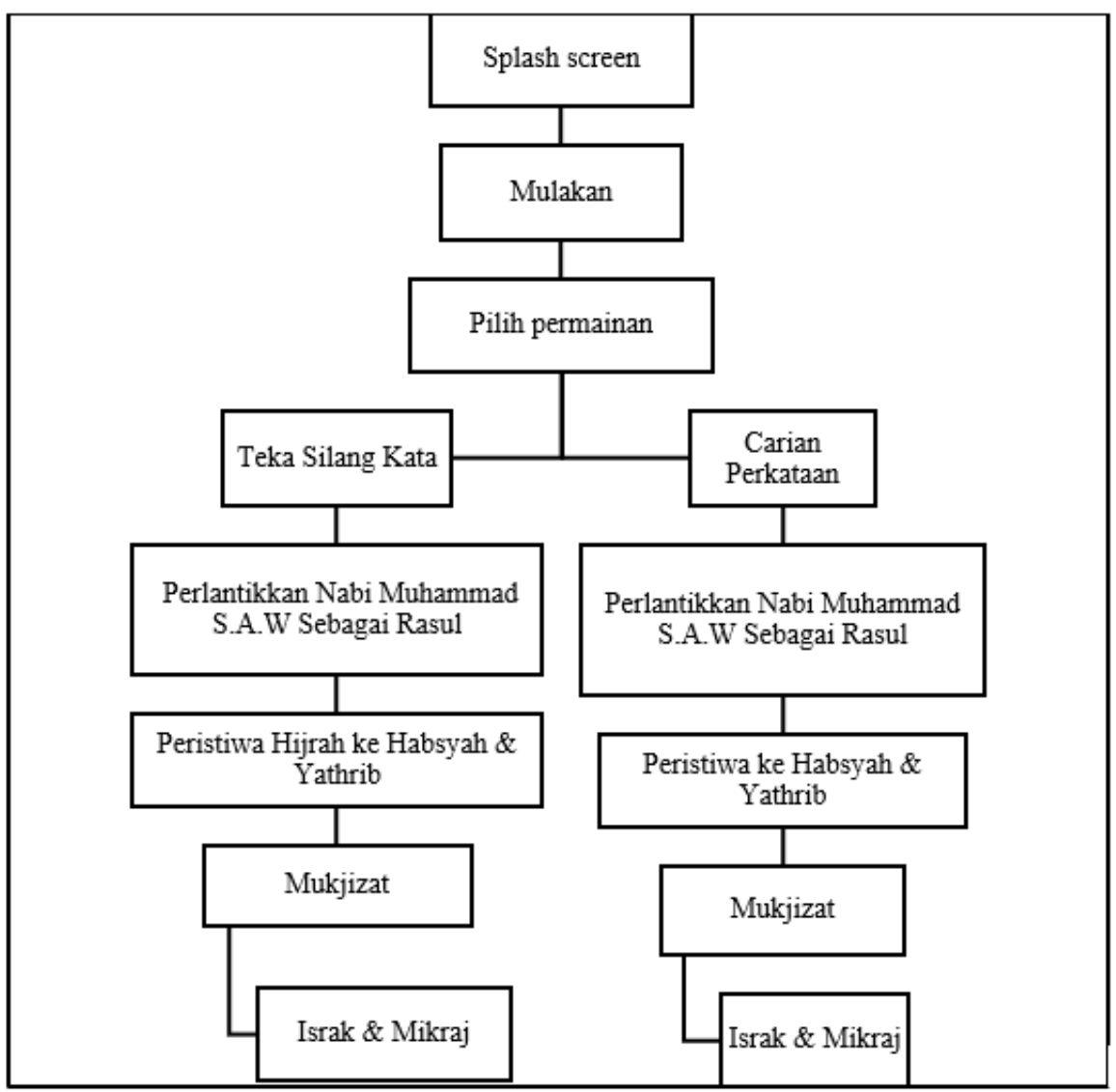

Figure 3: Modules of Sirah Educational Games

iii) Development Phase

Sirah mobile application was developed using Unity3d 2019 software; and as a platform to play Sirah app using Android and iOS. This game is still in the prototype version where it is not published on any platform yet. Therefore, for research purposes, the game is already installed in Samsung devices using an Android package (APK). This game is using C\# to code because it is compatible and easy to apply with unity software. Unity3d is a powerful cross-platform 3dimension (3D) engine and a user-friendly development environment (Ian Zamojc, 2012). It is an easy platform for the beginner but powerful for the expert user. Deliverables for this phase are Sirah Games Prototype. The Sirah Game prototype is shown in Figure 4. 

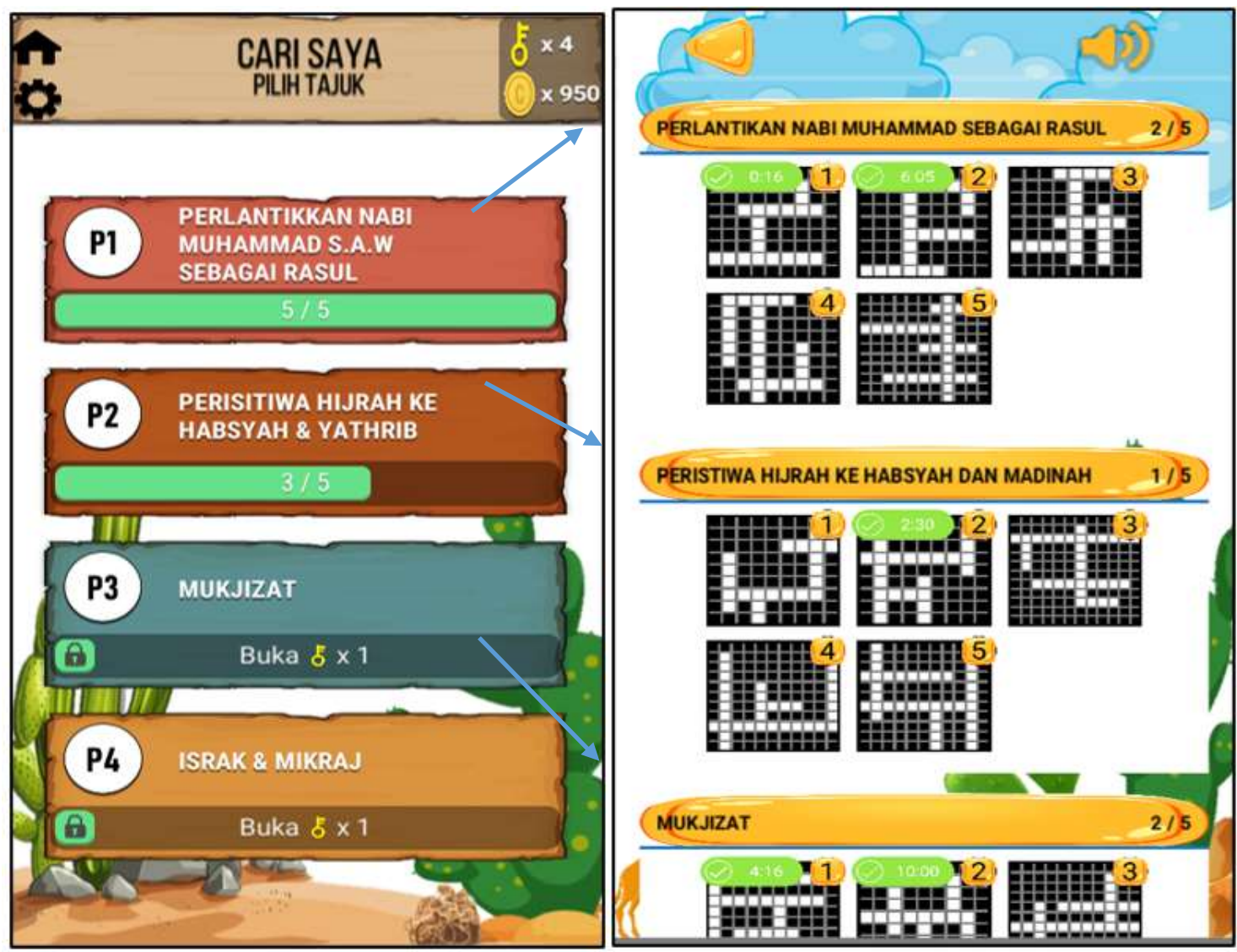

Figure 4: Game Modul Teka Silangkata

iv) Implementation Phase

In this phase, the games were tested by several students and teachers for their feedback and game refinement. Few feedbacks from students and teachers were collected for refinement purposes. The experiments are conducted on the 5 selected respondents at the beginning of the study. Respondents are likely to use the mobile app and every respondent response will be taken into account for upgrading. The Implementation Phase of this study was done during the pilot study.

v) Evaluation Phase

In this phase the game was evaluated using the usability proposed model as in Figure 2 . The game was evalauted by 38 students from SK Bukit Tinggi, Kepala Batas and SAR Dato' Abdullah, Rembau. They have answered the questionnaire after they finished playing the Sirah game. Both of the schools use the same syllabus that matches with the game content. For data collection purposes, the respondents were given the installed games on the mobile application. Due to a limited number of mobile devices, only a few students can use the games at any given time. Several rounds of data collectino was done to get a better number of repsondents.

Considering the sample size, this research implements the quantitative research methodology and questionnaire as a research instrument to collect data from the end-users. A set of questionnaires containing 29 questions divided into 7 sections (game usability, mobility, learning content, playability, satisfaction, efficiency and learnability) was developed and some selfdeveloped questions were based on the interview with 4 experts during a content validity process. All components were adapted and modified for the content of this research. A 3-points Likert Smileymometer scale was used to obtain the results. Adaptation was made because young children cannot easily distinguish between certain points in the basic 7-Likert point scale (Duh et al., 
2017).The Smiling face was used for "like" answer, "sad" face for "dislike" and the neutral face was presented with a straight-line.

Participants in this study were 38 students age 9 years old from Sekolah Kebangsaan Bukit Tinggi, Kepala Batas and Sekolah Agama Dato' Abdullah, Rembau. Five teachers from both schools were also interviewed to obtain their opinions on the game prototype. This study uses a quantitative approach using a survey for data collection. During the data collection process, a questionnaire was distributed after the student finished playing the game prototype. Data analysis was done using the SPSS statistical package.

\subsection{FINDINGS AND ANALYSIS}

a) Preliminary study result

Initial interviews with five Sirah teachers from the two schools were conducted in order to verify their opinions on mobile educational games in Sirah subject. It shows that 3 out of 5 teachers agreed if the mobile educational game was applied in school. The responses suggested that the use of mobile educational game among the student help the student to understand the subject and improve student grade.

b) Content Validity Index

To determine the relevancy of the instrument, the content validity index (CVI) was measure using quantitative approach. The researcher asked the expert to give their comments on the items generate for the study (Shrotryia \& Dhanda, 2019). A Likert scale was used to determine the relevancy of the items, where $1=$ Not relevant, $2=$ Quite relevant but needs minor revision and 3 = Highly relevant. A CVI accepted average is 0.898 (Shrotryia \& Danda., 2019). The only item rated as "Neutral" or "Like" were considered in calculating the CVI. The total CVI for this study is 0.983 , which is $>0.898$. This means that the items are relevant to the objective of the study.

c) Pilot test result

The pilot study was conducted after the Sirah Game was built and after getting permission from the students' guardians. The test was conducted at different places and times because the application was only installed on one smartphone. The overall result was quite satisfying where 3 out of 5 students are able to understand the game mechanics without any help from the researcher whereas 2 of them do not understand how the game work. From the pilot test, the results suggested that the game interface and the game mechanics were easy to understand.

d) Descriptive analysis

Based on Table 1, it can be seen that female respondent are more than male respondents with 25 females (65.8\%) compared to 13 males (34.2). Meanwhile, it was found that $15(39.5 \%)$ respondents spend 10-30 min playing phone in a day followed by $9(23.7 \%)$ respondent spent 5 $10 \mathrm{~min}$ and 30-60 min in a day and they are $5(13.1 \%)$ respondent who spent over than $60 \mathrm{~min}$ on phone in a day. Lastly, 21 (55.3\%) students were recorded playing mobile phone from 1-3 times a day followed by $7(18.4 \%)$ playing 7-9 times a day and $6(15.8 \%)$ played from 4-6 times a day and the least one is 4 (10.5) who play more than 9 times in a day. 
Table 1: Demographic Result

\begin{tabular}{|c|c|c|c|c|c|}
\hline \multicolumn{2}{|l|}{ Measures } & \multirow{2}{*}{$\begin{array}{c}\text { Frequency } \\
13\end{array}$} & \multirow{2}{*}{$\begin{array}{c}\text { Percent } \\
34.2\end{array}$} & \multirow{2}{*}{$\begin{array}{l}\text { Valid } \\
34.2\end{array}$} & \multirow{2}{*}{$\begin{array}{c}\text { Cumulative } \\
34.2\end{array}$} \\
\hline \multirow{3}{*}{ Gender } & Male & & & & \\
\hline & Female & 25 & 65.8 & 65.8 & 100 \\
\hline & Total & 38 & 100 & 100 & \\
\hline \multirow{5}{*}{$\begin{array}{l}\text { Time spent on playing phone in a } \\
\text { day }\end{array}$} & $5-10 \min$ & 9 & 23.7 & 23.7 & 23.7 \\
\hline & $10-30 \mathrm{~min}$ & 15 & 39.5 & 39.5 & 63.2 \\
\hline & $30-60 \mathrm{~min}$ & 9 & 23.7 & 23.7 & 86.3 \\
\hline & $>60 \mathrm{~min}$ & 5 & 13.1 & 13.1 & 100 \\
\hline & Total & 38 & 100 & 100 & \\
\hline \multirow{5}{*}{$\begin{array}{l}\text { Frequency on playing a phone in } \\
\text { a day }\end{array}$} & 1-3 times & 21 & 55.3 & 55.3 & 55.3 \\
\hline & 4-6 times & 6 & 15.8 & 15.8 & 71.1 \\
\hline & 7-9 times & 7 & 18.4 & 18.4 & 89.5 \\
\hline & $>9$ times & 4 & 10.5 & 10.5 & 100 \\
\hline & Total & 38 & 100 & 100 & \\
\hline
\end{tabular}

On the Game Usability result (Table 2), the average value for each item ranges from 2.05 to 2.97, with most of the medians at 3. GU1 has the highest score for attractive interfaces. The students also liked the color combination of the game (GU6). GU5 has the lowest score maybe because the students are not familiar with this type of game.

Table 1 Game Usability Result

\begin{tabular}{|l|l|c|c|c|c|}
\hline \multicolumn{1}{|c|}{ Items } & Mean & Median & Mode & Std. Dev \\
\hline GU1 & Paparan antaramuka dan grafik sangat menarik & 2.97 & 3 & 3 & .16 \\
\hline GU2 & $\begin{array}{l}\text { Bentuk teks dan warna teks digabung dengan baik } \\
\text { dan teratur. }\end{array}$ & 2.71 & 3 & 3 & .57 \\
\hline GU3 & $\begin{array}{l}\text { Peraturan permainan yang jelas dan mudah } \\
\text { difahami. }\end{array}$ & 2.71 & 3 & 3 & .46 \\
\hline GU4 & $\begin{array}{l}\text { Saiz teks dan bentuk huruf yang digunakan dalam } \\
\text { permainan ini mudah dibaca. }\end{array}$ & 2.76 & 3 & 3 & .59 \\
\hline
\end{tabular}




\begin{tabular}{|l|l|c|c|c|c|}
\hline GU5 & $\begin{array}{l}\text { Saya tidak perlu menghafal cara untuk bermain } \\
\text { permainan ini. }\end{array}$ & 2.05 & 2 & 3 & .84 \\
\hline GU6 & $\begin{array}{l}\text { Warna yang digunakan dalam permainan ini } \\
\text { menarik. }\end{array}$ & 2.87 & 3 & 3 & .41 \\
\hline
\end{tabular}

For the Learnability part, the mean for each item ranges from 2.37 to 2.71 with median and mode at 3. Most of the students think that they can easily learn the game becausethe game is quite straightforward. Even though, they can easily learn the game, some of them still need to understand the game before they play (Table 3).

Table 2 Learnability Result

\begin{tabular}{|c|c|c|c|c|c|}
\hline & Items & Mean & Median & Mode & Std. Dev \\
\hline LA1 & $\begin{array}{l}\text { Saya perlu tahu beberapa perkara sebelum saya } \\
\text { dapat bermain permainan ini. }\end{array}$ & 2.37 & 3 & 3 & .79 \\
\hline LA2 & Senang untuk saya mempelajari permainan ini. & 2.71 & 3 & 3 & .52 \\
\hline LA3 & $\begin{array}{l}\text { Saya rasa, semua orang akan dapat bermain } \\
\text { permainan ini dengan cepat. }\end{array}$ & 2.55 & 3 & 3 & .69 \\
\hline
\end{tabular}

For the PA result (Table 4), the mean for each item in this range is from 2.45 to 2.76, with a median and mode of 3 for each item. Most of them said that the game is not boring (PA3) because they are many levels and they could win coins if they managed to complete the levels.

Table 3: Playability Result

\begin{tabular}{|l|l|c|c|c|c|}
\hline & \multicolumn{1}{|c|}{ Items } & Mean & Median & Mode & Std. Dev \\
\hline PA1 & Permainan ini mantap/teratur. & 2.45 & 3 & 3 & .69 \\
\hline PA2 & $\begin{array}{l}\text { Saya diberikan ganjaran seperti duit dan catatan masa } \\
\text { terpantas dalam permainan ini }\end{array}$ & 2.61 & 3 & 3 & .68 \\
\hline PA3 & Permainan ini tidak membosankan. & 2.76 & 3 & 3 & .63 \\
\hline PA4 & Cabaran dan tahap permainan adalah seimbang. & 2.68 & 3 & 3 & .47 \\
\hline
\end{tabular}

In response to the efficiency component (Table 5), the mean for each item in this range is from 2.03 to 2.47, with median 3 except for EF3 items and a mode of 3 for each item except for EF3 which is 2 and 3. Most of the students managed to finish the levels on their first try (EF2); according to them, the level was easy, and they already learn the subject during class. 
Table 4: Efficiency Result

\begin{tabular}{|l|l|c|c|c|c|}
\hline & \multicolumn{1}{|c|}{ Items } & Mean & Median & Mode & Std. Dev \\
\hline EF1 & Saya boleh bermain permainan ini tanpa bantuan. & 2.03 & 3 & 3 & .75 \\
\hline EF2 & $\begin{array}{l}\text { Saya boleh menamatkan tahap permainan ini dalam } \\
\text { percubaan pertama. }\end{array}$ & 2.47 & 3 & 3 & .65 \\
\hline EF3 & $\begin{array}{l}\text { Kesalahan dan kesilapan yang dilakukan oleh saya } \\
\text { semasa bermain permainan ini adalah sedikit. }\end{array}$ & 2.34 & 2 & 3 & .67 \\
\hline EF4 & $\begin{array}{l}\text { Saya tahu bagaimana untuk pulih dari kesilapan jika } \\
\text { saya tersilap menekan butang dalam permainan. }\end{array}$ & 2.45 & 3 & 3 & .69 \\
\hline
\end{tabular}

The mean for each item in LC (Table 6) is from 2.68 to 2.89, with median and mode of 3 for each item. Most of the student agreed that this game has Sirah learning content (LC1), this is because the topic is the same with the textbook that provided by JAKIM. They also think that this game will help them in learning Sirah in a fun way.

Table 5: Learning Content Result

\begin{tabular}{|c|c|c|c|c|c|}
\hline & Items & Mean & Median & Mode & Std. Dev \\
\hline LC1 & $\begin{array}{l}\text { Permainan ini mengandungi kandungan } \\
\text { pembelajaran mengenai Sirah. }\end{array}$ & 2.89 & 3 & 3 & .31 \\
\hline LC2 & Saya belajar Sirah elalui permainan ini. & 2.68 & 3 & 3 & .62 \\
\hline LC3 & $\begin{array}{l}\text { Saya boleh belajar Sirah dengan mudah melalui } \\
\text { permainan ini }\end{array}$ & 2.74 & 3 & 3 & .50 \\
\hline LC4 & Permainan ini membantu saya dalam pelajaran Sirah. & 2.87 & 3 & 3 & .34 \\
\hline
\end{tabular}

For Satisfaction components (Table 7), the mean for each item in this range is from 2.68 to 2.92 , with median and mode of 3 for each item. Most of the students think that this game is enjoyable and fun to play. They are happy to get the point when they finished the level.

Table 6: Satisfaction Result

\begin{tabular}{|l|l|c|c|c|c|}
\hline & Items & Mean & Median & Mode & Std. Dev \\
\hline SF1 & Saya hendak bermain permainan ini lagi. & 2.79 & 3 & 3 & .58 \\
\hline SF2 & Permainan ini menyeronokkan. & 2.97 & 3 & 3 & .16 \\
\hline SF3 & $\begin{array}{l}\text { Saya hendak bermain permainan ini dengan } \\
\text { kawan saya. }\end{array}$ & 2.68 & 3 & 3 & .62 \\
\hline SF4 & Permainan ini sangat senang untuk dimainkan. & 2.68 & 3 & 3 & .53 \\
\hline
\end{tabular}


\begin{tabular}{|l|l}
\hline SF5 & Saya akan tersenyum jika saya mendapat mata
\end{tabular} dan dapat mennyelesaikan permainan ini.
2.92
.27

Lastly, the statistical analysis result for the Mobility component (Table 8) shows the mean for each item in this range from 2.58 to 2.76 , with median and mode of 3 for each item. This shows that the game can be played at any time and place that they prefer.

Table 7: Mobility Result

\begin{tabular}{|l|l|c|c|c|c|}
\hline & \multicolumn{1}{|c|}{ Items } & Mean & Median & Mode & Std. Dev \\
\hline MO1 & $\begin{array}{l}\text { Jika apa-apa berlaku, permainan boleh disimpan } \\
\text { secara automatik. }\end{array}$ & 2.58 & 3 & 3 & .60 \\
\hline MO2 & Permainan boleh dimulakan dengan cepat. & 2.76 & 3 & 3 & .43 \\
\hline MO3 & $\begin{array}{l}\text { Saya boleh menyimpan permainan ini jika saya } \\
\text { tidak mahu bermain, dan saya boleh menyambung } \\
\text { permainan pada bila-bila masa. }\end{array}$ & 2.68 & 3 & 3 & .57 \\
\hline
\end{tabular}

\subsection{DISCUSSION AND CONCLUSION}

This study on Mobile Educational Games for Learning Sirah Nabi: Design and Usability Evaluation was divided into two phases: Sirah Game Prototype Design and Usability Evaluation phase; using ADDIE, an instructional model to guide the design process. An important subject like Sirah can be dull and uninspiring to young students. A more innovative learning approach to overcome these problems was proposed such that students can learn Sirah in a better way and more effectively. On the Game Usability result, the average value for each item ranged from 2.05 to 2.97 , with most of the medians at 3 . The attractive interfaces received the highest score. The students also liked the color combination of the game; the "need to learn" the game has the lowest score maybe because the students were not familiar with this type of game.

For the Learnability part, the mean for each item ranged from 2.37 to 2.71 with median and mode at 3. Most of the students think that they can easily learn the game (although they were unfamiliar with it) because the game was quite straightforward. In other words, even though, they can easily learn the game, some of them still need to understand the game before they play. For the Playability results, the mean for each item in this range was from 2.45 to 2.76, with a median and mode of 3 for each item. Most of the respondents said that the game was not boring because they are many levels, and they could win "tokens" if they managed to complete the levels.

In response to the Efficiency component, the mean for each item in this range was from 2.03 to 2.47. The respondents indicated that they made many errors. Most of the students managed to finish the early levels on their first try; according to them, the levels were easy because they had already learned the subject during class. The mean for each item in Learning Content is from 2.68 to 2.89 , with median and mode of 3 for each item. Most of the students agreed that this game has Sirah learning content, this is because the topic is the same as the textbook that they were using. They also think that this game will help them in learning Sirah in a fun way.

For Satisfaction components, the mean for each item in this range was from 2.68 to 2.92, with median and mode of 3 for each item. Most of the students thought that this game was enjoyable 
and fun to play. They are happy to get the point when they finished the level. Lastly, the statistical analysis result for the Mobility component shows the mean for each item in this range from 2.58 to 2.76 , with median and mode of 3 for each item. This shows that the game can be played at any time and place that they prefer.

To surmise the study found that the students were at first exposure unfamiliar with the game and need to aquaint themselves with the game with some initial guidance as well as making mistakes, they were quick to learn the game as it was easy to learn. Once they were comfortable with the mechanics of the game, they were learning the subject albeit it was a reinforcement on topics they had studied in class. Aboveall, they recognized the relevancy of the game content and they enjoyed the learning process that was effective. In conclusion, it can be surmised the study supports the proposition that properly designed educational mobile game assists and motivates students to learn especially low-interest subjects in a fun way with the flexibility of learning at any time and at any place.

\section{Acknowledgement}

This study is funded by Universiti Teknologi Malaysia under Research Unversity Grant with vote number 21H15. We appreciate the helps and supports we received from UTM, Research Management Centre and Faculty Technology and Informatics Razak.

\section{References}

Barnes, T., et al. Game2Learn: Building CS1 Learning Games for Retention. in ITiCSE’07. 2007. Dundee, Scotland, United Kingdom.

Bevan, N. (1998). ISO 9241: Ergonomic requirements for office work with visual display terminals (VDTs)—Part 11: Guidance on usability. TC159.

Castillo, R. E. et al. (2019) 'Development of an educational mobile game applications for Grade 5 for Knowledge Channel Inc.', ACM International Conference Proceeding Series, Part F148384(02), 99104. doi: $10.1145 / 3322645.3322695$.

Chee-Huay, C. and Kee-Jiar, Y. (2015) 'Why Students Fail in History: A Minor Case Study in Malaysia and Solutions from Cognitive Psychology Perspective', Mediterranean Journal of Social Sciences, 7(1), 517-526. doi: $10.5901 / \mathrm{mjss} .2016 . v 7 n 1 \mathrm{p} 517$.

Duh, E. S., Koceska, N. and Koceski, S. (2017) 'Game-based learning: educational game Azbuka to help young children learn writing Cyrillic letters', Multimedia Tools and Applications. Multimedia Tools and Applications, 76(12), pp. 14091-14105. doi: 10.1007/s11042-016-3829-9.

Harrison, R., Flood, D., \& Duce, D. (2013). Usability of mobile applications: Literature review and rationale for a new usability model. Journal of Interaction Science, 1(1), 1-16. How do Game Engines Work. (2016, November 2). Retrieved March 20, 2019 from https://interestingengineering.com/how-gameengines-work

Hidayanto, D. R. et al. (2017) 'The application of ADDIE model in developing adventure game-based multimedia learning to improve students' understanding of basic programming', Proceeding - 2017 3rd International Conference on Science in Information Technology: Theory and Application of IT for Education, Industry and Society in Big Data Era, ICSITech 2017, 2018-January(June 2018), 307-312. doi: 10.1109/ICSITech.2017.8257130.

Ian Zamojc (2012, May 17) Introduction to Unity3D. Retrieved November 1, 2019, from https://code.tutsplus.com/tutorials/introduction-to-unity3d--mobile-10752

Ibharim, L. F. M. and Yatim, M. H. M. (2014) 'BBUAT: Paper prototyping of interactive game design authoring tool for children', Lecture Notes in Computer Science (including subseries Lecture Notes in Page | 119 
Artificial Intelligence and Lecture Notes in Bioinformatics), 8778, 82-92. doi: 10.1007/978-3-31911623-5_8.

Jaffar, M. Najib, Rahman A. Azman, Zakaria, M. Anwar, Yeap, Mursyid, Shakor, M. Faiz (2020). Tahap Keberkesana Gamifikasi Global Halal Game dalam Kalangan Peserta Program Halal Eksekutif. UMRAN International Journal of Islamic and Civilizational Studies.7(3), 45-58.

Jaspaljeet, S.L.L.W., Mohana S,Saraswathy S. G, Siva K.D., Designing Computer Games to Introduce Programming to Children, in Information Technology and Multimedia at UNITEN (ICIMU' 2008), Uniten, Editor. 2008: Selangor, Malaysia. 643-647.

Jou, M., Tennyson, R. D., Wang, J., \& Huang, S.-Y. (2016). A study on the usability of E learning system. Journal of Information Technology Education: Innovations in Practice, books and APP in engineering courses: A case study on mechanical drawing. 11(1), 94-119. Computers \& Education, 92, 181-193.

Korhonen, H. and Koivisto, E. M. I. (2007) 'Playability heuristics for mobile multi-player games', ACM International Conference Proceeding Series, 274, 28-35. doi: 10.1145/1306813.1306844.

Lee Chong Hui (2017, August 06) Are you game for it?. The Star. Retrieved March 15, 2019, from https://www.thestar.com.my/news/education/2017/08/06/are-you-game-for-it

Marissa, V.S., Ibrahim, R. (2019). A Review of Heuristics Component for Usability Evaluation of Mobile Educational Games. Open International Journal of Informatics (OIJI). 7 (2), 190-199.

Nielsen, J. (1994). Usability engineering. Morgam Kaufmann. Elsevier. USA. ISBN 9780125184069

Nielsen, J., \& Budiu, R. (2013). Mobile Usability. Pearson. USA.

Olsen, T., Procci, K. and Bowers, C. (2011) 'Serious games usability testing: How to ensure proper usability, playability, and effectiveness', Lecture Notes in Computer Science (including subseries Lecture Notes in Artificial Intelligence and Lecture Notes in Bioinformatics), 6770 LNCS(PART 2), 625-634. doi: 10.1007/978-3-642-21708-1_70.

Paiva, A. C. R. et al. (2016) 'iLearnTest - Framework for Educational Games', Procedia - Social and Behavioral Sciences. The Author(s), 228(June), pp. 443-448. doi: 10.1016/j.sbspro.2016.07.068.

Parsazadeh, N. et al. (2018) 'The construction and validation of a usability evaluation survey for mobile learning environments', Studies in Educational Evaluation. Elsevier, 58(August 2017), 97-111. doi: 10.1016/j.stueduc.2018.06.002.

Rashid, N. A. B. M., Salleh, S. B. M. and Noor, N. B. M. (2019) 'Development of Jawi spelling skills applications, "Oh Jawiku", International Journal of Interactive Mobile Technologies, 13(7), 80-89. doi: 10.3991/ijim.v13i07.10759.

Ibrahim, Roslina et al, (2017). Student Acceptance of Educational games in higher Education. Journal of Fundamental and Applied Sciences, 9 (3S), 809-829.

Ibrahim, Roslina et al., Students Perceptions of Using Educational Games to Learn Introductory Programming. Computer and Information Science, 2011. 4(1), 205 - 216.

Sasaki, T. et al. (2017) 'Japanese history explorer with nozomi-chan for elementary school children', Proceedings of the 11th European Conference on Games Based Learning, ECGBL 2017, (October), 562-570.

Shitkova, M., Holler, J., Heide, T., Clever, N., \& Becker, J. (2015). Towards usability guidelines for mobile websites and applications. Wirtschaftsinformatik. 1603-1617.

Scepanovic, S. and Radunovic, P. (2015) 'Game based mobile learning-application development and evaluation', The Sixth International Conference on e-Learning, (September), 24-25. https://pdfs.semanticscholar.org/1542/10e2a2f658f4b3c2ada05429cae884d6c1c5.pdf. 
Shrotryia, Vijay \& Dhanda, Upasana. (2019). Content Validity of Assessment Instrument for Employee Engagement. SAGE Open. 9. 215824401882175. 10.1177/2158244018821751.

Statistik keputusan UPKK 2015 Peringkat Kebangsaan. (2016, January 15). PerguKafaKuantan. Retrieved March 20, 2019 from https://www.pergukafakuantan.com/2016/01/statistik-keputusan-upkk-2015peringkat.html

Suhaila Shahrul Annuar (2018, December 18) Peratusan lulus UPKK 2018 cemerlang. Harian Metro. Retrieved March 20, 2019, from https://www.hmetro.com.my/mutakhir/2018/12/404335/peratusan-lulus-upkk-2018-cemerlangmetrotv.

Nagalingam, V. Ibrahim, R. (2020). EDUGXQ: User Experience Elements for Educational Games. International Journal of Advanced Computer Science and Applications. 11 (1), 562-569.

Zaibon, S. B. (2015) 'User Testing On Game Usability, Mobility, Playability, and Learning Content of Mobile Game-Based Learning', Jurnal Teknologi, 1, 131-139.

Zanariah Abd Mutalib (2017, February 15) 46,461 calon UPKK semua A. Berita Harian. Retrieved March 20, 2019, from https://www.bharian.com.my/node/248487. 